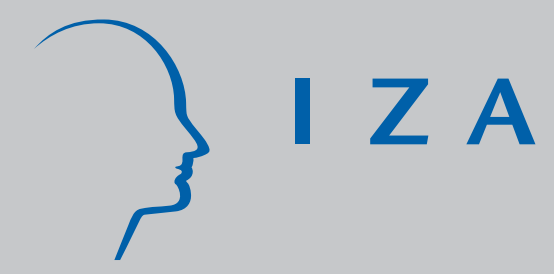

IZA DP No. 951

Raising Female Employment:

Reflexions and Policy Tools

Pietro Garibaldi

Etienne Wasmer

December 2003 


\title{
Raising Female Employment: Reflexions and Policy Tools
}

\author{
Pietro Garibaldi \\ Bocconi University, IGIER, \\ CEPR and IZA Bonn \\ Etienne Wasmer \\ ECARES, Free University of Brussels, \\ University of Metz, CEPR and IZA Bonn
}

\section{Discussion Paper No. 951 December 2003}

\author{
IZA \\ P.O. Box 7240 \\ D-53072 Bonn \\ Germany \\ Tel.: +49-228-3894-0 \\ Fax: +49-228-3894-210 \\ Email: iza@iza.org
}

This Discussion Paper is issued within the framework of IZA's research area The Future of Labor. Any opinions expressed here are those of the author(s) and not those of the institute. Research disseminated by IZA may include views on policy, but the institute itself takes no institutional policy positions.

The Institute for the Study of Labor (IZA) in Bonn is a local and virtual international research center and a place of communication between science, politics and business. IZA is an independent, nonprofit limited liability company (Gesellschaft mit beschränkter Haftung) supported by Deutsche Post World Net. The center is associated with the University of Bonn and offers a stimulating research environment through its research networks, research support, and visitors and doctoral programs. IZA engages in (i) original and internationally competitive research in all fields of labor economics, (ii) development of policy concepts, and (iii) dissemination of research results and concepts to the interested public. The current research program deals with (1) mobility and flexibility of labor, (2) internationalization of labor markets, (3) welfare state and labor market, (4) labor markets in transition countries, (5) the future of labor, (6) evaluation of labor market policies and projects and (7) general labor economics.

IZA Discussion Papers often represent preliminary work and are circulated to encourage discussion. Citation of such a paper should account for its provisional character. A revised version may be available on the IZA website (www.iza.org) or directly from the author. 
IZA Discussion Paper No. 951

December 2003

\section{ABSTRACT}

\section{Raising Female Employment: Reflexions and Policy Tools*}

While there is consensus on the need to raise the time spent in the market by European women, it is not clear how these goals should be achieved. Tax wedges, assistance in the job search process, and part-time jobs are policy instruments that are widely debated in policy circles. The paper presents a simple model of labour supply with market frictions and heterogenous home production where the effects of these policies can be coherently analysed. We show that subsidies to labour market entry increase women's entrance in the labour market, but they also increase exits from the labour market, with ambiguous effect on employment. Subsidies to part-time do increase employment, but they have ambiguous effects on hours and market production. Finally, reductions in taxes on market activities that are highly substitutable with home production have unambiguous positive effects on market employment and production.

JEL Classification: J0, J2

Keywords: employment rate, market frictions, labour market policy

Corresponding author:

Etienne Wasmer

ECARES

Université Libre de Bruxelles

CP 114

Avenue Franklin D. Roosevelt 39

1050 Brussels, Belgium

Tel.: +322650 4212

Fax: +32 26504475

Email: ewasmer@ulb.ac.be

* We thank Tito Boeri and seminar participants at the $18^{\text {th }}$ Conference of the European Economic Association held in Stockholm on August 20-24, 2003. 


\section{Introduction}

The low level of female employment in most South European countries has attracted a great deal of attention by national and European policy makers. There are indeed huge differences across Member States in the share of employed women in the working age population, which is currently around 40 percent in countries such as Spain, Italy and Greece and around 70 percent in Nordic countries (see Pissarides et al. 2003). At the intensive margin, recently collected empirical evidence on use of time shows that the average North American and German women spend the same share of time in leisure activities (Freeman and Schettkat, 2002). Yet, the allocation of time between market and home production varies greatly between the two countries, with North American women spending on average 5.3 more hours per day in market activities than German women. Further, most of this difference comes from differences in the extensive margin, with a large share of women in Germany devoted full time in home production (childcare, preparing meals, cleaning, etc.).

A fervid debate is currently devoted to finding specific policies that may raise female employment rates. These policies should increase women's incentives to substitute household production with market production, so as to increase the equilibrium level of employment and the size of official GDP. While there is a large consensus on the need to raise the time spent in the market by European women, there is some confusion over how these goals should be achieved. Reducing the high tax wedge, developing part-time work and improving assistance in the job search process are often mentioned policies, but their different effects are rarely discussed in a unified way. This generates some confusion. For instance, a natural question about part-time is whether it should be strongly encouraged, or whether one should simply avoid making part-time jobs unattractive relative to full-time jobs ${ }^{1}$. However, this type of question is rarely explicitly formulated. We believe that part of the confusion over

\footnotetext{
${ }^{1}$ Typically part-time jobs are associated with less health insurance, less employment protection and lower unemployment benefits.
} 
the role and the effect of these various policies is linked to the lack of a unified analytical model where the different set of policies can be coherently analyzed. The goal of this paper is to propose such a framework.

To contribute to the debate, two key features of the labour market must necessarily be considered. The first element is heterogeneity in individual's utility in non-market time (e.g. the ability to produce at home or the utility of leisure). The second element is the existence of imperfections in the labour market. In this paper we build on the recent work of Garibaldi and Wasmer (2003) who have developed a theory of labour supply for a frictional labour market. In particular, they showed that when labour market participation involves an irreversible entry cost and market production is indivisible, the entry and exit decisions differ, and the participation decision is described by a double margin. Since the different policies described above affect the two margins differently, and sometimes have an opposite impact (e.g. raise the propensity to enter the labor market while at the same time raise the propensity to leave the labor market), we need to clarify the effects of female employment policies on employment rates, market production and welfare.

We consider the three policies discussed above in details: subsidies to labour market entry, taxation to market activity and subsidies to part time. With respect to subsidies to labour market entry (which can also be interpreted as subsidies to mobility), the paper shows that they lead to an increase in the number of women entering the labour market. Yet, the overall effect on total employment can be ambiguous, since subsidies tend to reduce participation hoarding and thus increase exits from the market. ${ }^{2}$ Less ambiguous and more standard results derive from the effects of taxation on market activities, which have nonneutral effects on participation since household production can not be taxed. Our analysis

\footnotetext{
${ }^{2}$ Participation hoarding is defined as the willingness to participate to the labor market even though the felicity derived from home production is larger than the wage, in order to save on future re-entry costs in case of a change in either wages or home production. See Garibaldi and Wasmer (2003).
} 
shows that a reduction in taxes leads to both larger entry and lower exit with unambiguous positive effect on total employment. These results are consistent with the recent work of Davis and Henrekson (2003) and Prescott (2002). Finally, we discuss also the effects of part-time. Our theory shows that an increase in part-time should never be banned, and any form of implicit obstacle should be removed. Yet, our results show that a subsidy to part time has two opposite effects on market production. If it indeed induces women that are full time in home production to enter part-time in the labour market (crowding in effect), it can also induce some women who are working full time in the market to swap to parttime (a crowding out effect). The overall effect on market production is thus ambiguous and depends on how the mass of women is positioned around the initial equilibrium. Nevertheless, if the distribution of home productivity is single peaked, the positive effect on employment dominates if and only if the marginal participant is to the left of the peak of the distribution, or in words, when the employment rate is low.

The paper proceeds as follows. Section 2 derives the set-up, the reservation strategies of workers and introduces a definition of welfare and expressions for aggregate home production, employment and hours. Section 3 investigates the role of subsidies to entry and taxes. Section 4 deals with part-time. Section 5 concludes.

\section{Labour Supply on the Extensive Margins in an Im- perfect Labor Market}

\subsection{Set-up}

In this section we extend the baseline model of labour supply with market frictions proposed by Garibaldi and Wasmer (2003). These extensions help us to discuss two policies that are widely debated in the discussion over female employment: the effects of marginal income taxes and policies aimed at facilitating entrance in the labour market. The role of part-time will be discussed in the next section. 
We assume that a mass one of women enjoys utility from home production and market production. Women have a unit of time to be spent in market and home production, two activities that we assume to be perfect substitutes. This is a strong assumption, but we maintain it throughout the paper for analytical simplicity, since it implies that women will specialize in the activity in which they are most productive. We assume that hours spent in market production are exogenously fixed and equal to one. In other words, market production is a full time activity, and our emphasis is on the extensive margin of labour supply. In market production people are paid a gross wage net of taxes, so that the take home pay for a full day in the market is $y=w(1-t)$, where $t$ is the tax rate. Utility from home production is heterogenous and stochastic and its value changes according to a Poisson at rate $\lambda$. A full day in home production yields a per period utility equal to $x$, where $x$ is drawn from a continuous cumulative distribution $F(x)$ defined over the support $\Omega=\left[x_{\min ,} x^{\max }\right]$. Further, home production cannot be taxed. The per period utility of women is

$$
\begin{aligned}
& v^{w}=w(1-t) \\
& v^{H}=x
\end{aligned}
$$

The key worker decision involves the time to be spent in market production. In absence of frictions in the market, the model is trivial and the participation decision is described by a single reservation value $x^{*}=w(1-t)$, so that all individuals with home production below $x^{*}$ participate full time in market activity. In reality, information on the location and the availability of jobs is not perfect, and the process of information gathering is akin to paying an irreversible entry cost equal to $\mathcal{C}$. Indeed, in our previous research we have shown that from the labour supply standpoint modelling the search process as a time consuming process is identical to assuming that entering the labour market involves an irreversible entry cost. In the current paper, we keep the irreversible cost assumption, and we assume that $\mathcal{C}$ is determined by both technological and policy dimensions. Job search assistance and training and mobility subsidies represent the policy dimension: both aims at reducing the irreversible 
cost paid by market entrance.

\section{$2.2 \quad$ Reservation strategies}

The existence of the irreversible $\operatorname{cost} \mathcal{C}$ induces a distinction of the entry and exit decision. If we indicate with $H$ the value function for being full time in home production and with $W$ the value function for being full time in market production, the two margins are defined as

$$
\begin{aligned}
\text { Entry }: & H\left(x^{\nu}\right)=W\left(x^{\nu}\right)-\mathcal{C} \\
\text { Quit }: & H\left(x^{q}\right)=W\left(x^{q}\right),
\end{aligned}
$$

where $x^{\nu}$ is the entry cut-off point and $x^{q}$ is the exit cut-off point. To determine an expression for the two cut off points requires some algebra, since the intertemporal nature of the model does play a role. Formally, the value function of being in market activity reads

$$
r W(x)=w(1-t)+\lambda\left[\int \operatorname{Max}[W(z), H(z)] d F(z)-W(x)\right]
$$

where $r$ is the pure rate of time preferences. The equation has a standard asset value interpretation, and the integral in the right hand side simply says that conditional on a change in home productivity, the woman reoptimizes her position on the extensive margin. Similarly, the value of being full time in home production reads

$$
r H(x)=x+\lambda\left[\int \operatorname{Max}[W(z)-\mathcal{C}, H(z)] d F(z)-H(x)\right]
$$

Developing the algebra of the two margins, one obtains two equations for the two cut-off points whose expression read

$$
\begin{gathered}
\frac{x^{q}-x^{\nu}}{r+\lambda}=\mathcal{C} \\
x^{q}=x^{*}+\frac{\lambda}{r+\lambda} \int_{x^{\nu}}^{x^{q}} F(z) d z .
\end{gathered}
$$

The first equation, The entry margin shows that the surplus on the job (the left hand side in the equation) is equal to the entry cost. It also shows that when the entry cost is positive, 
$x^{q}>x^{\nu}$. The second equation, the quit margin, says in the case of positive $\mathcal{C}$, the quit cut-off points is above the frictionless cutoff point $x^{*}$ by an extra term that reflects the fact that women hold on to market production as a way to save future entry costs if home production were to change. Note that the two equations can be described by two lines in a $\left[x^{q}, x^{\nu}\right]$ space. The entry margin is upward sloping and it is parallel to the 45 degree line. It is also easy to show that the quit margin is downward sloping as long as $\lambda>0$, and is a horizontal line at $x^{*}$ when $\lambda=0$. The cut-off point equilibrium is given by the intersection of the two lines. We use this graphical representation in Figure 1 below to analyse the effect of policies. Note that the two equations (Entry) and (Quit) imply that as friction disappears $(\mathcal{C}=0)$ the two cut-off point coincide with the net wage. In Garibaldi and Wasmer (2003), we showed that the cut-off points are such that

$$
x^{q} \geq x^{*} \geq x^{\nu}
$$

where $x^{*}=w(1-t)$ is the frictionless participation margin, i.e. the neoclassical reservation rule, and strict inequality holds whenever $\mathcal{C}>0$.

\subsection{Employment, market production and welfare}

The model is then closed by the determination of the stock of employed and non-employed people. Developing the algebra, the steady stock of employed people is

$$
\begin{aligned}
e & =\frac{F\left(x^{\nu}\right)}{1+F\left(x^{\nu}\right)-F\left(x^{q}\right)} \\
n & =1-e=\frac{1-F\left(x^{q}\right)}{1+F\left(x^{\nu}\right)-F\left(x^{q}\right)}
\end{aligned}
$$

where $e$ is total employment and it increases with both margins while $n$ is non-employment and falls with both margins. To define aggregate home production $H$ and $G D P$, we need to take into account the fact that not all workers between the two cut-off points are engaged in full time production, since some of them are also employed. Denote by $\alpha<1$ the fraction 
of non-employed workers between $x^{\nu}$ and $x^{q}$. It is easy to show that $\alpha=n .{ }^{3}$ Market GDP and aggregate home production $H$ are thus defined as

$$
\begin{aligned}
H & =\alpha \int_{x^{\nu}}^{x^{q}} x d F(x)+\int_{x^{q}}^{x^{\max }} x d F(x) \\
G D P & =\int_{x^{\min }}^{x^{\nu}} y d F(x)+(1-\alpha) \int_{x^{\nu}}^{x^{q}} y d F(x)=y e
\end{aligned}
$$

The second equality in the GDP definition states that total production is simply proportional to employment since the choice of hours is inelastic. Note also that the net wage $w$ is assumed to decrease by one to one when $t$ increases so that the marginal product $y$ is constant. Accordingly, taxes affect market GDP only through their effects on cutoff points.

Finally, welfare is the sum of both home and market production net of entry costs, i.e.

$$
\mathcal{W}=n \int_{x^{\nu}}^{x^{q}} x d F(x)+\int_{x^{q}}^{x^{\max }} x d F(x)+y(1-n)-\lambda F\left(x^{\nu}\right) n \mathcal{C}
$$

where the last part is simply the steady-state number of entrants to the labor markets multiplied by their entry cost.

\section{Subsidies to entry to the labor market and reduc- tions in taxation}

\subsection{The Effects of Reducing The Irreversible Entry Cost}

We now want to consider the effect of two possible policies for increasing employment The first one is a subsidy to labor market entry, which can also be interpreted as a subsidy to mobility or a subsidy job search assistance. All interpretations are consistent with a reduction in the entry $\operatorname{cost} \mathcal{C}$ at the individual level. Such a reduction in $\mathcal{C}$ will induce an

\footnotetext{
${ }^{3}$ It is easy to verify that the number of employed workers below $x^{\nu}$ is $F\left(x^{\nu}\right)$ while the number of inactive workers above $x^{q}$ is $1-F\left(x^{q}\right)$. Between $x^{\nu}$ and $x^{q}$, one finds both employed and non-employed workers. Unreported steady-states conditions on stocks imply that

$\alpha=\frac{n-\left(1-F\left(x^{q}\right)\right)}{n-\left(1-F\left(x^{q}\right)\right)+e-F\left(x^{\nu}\right)}=n$.
} 

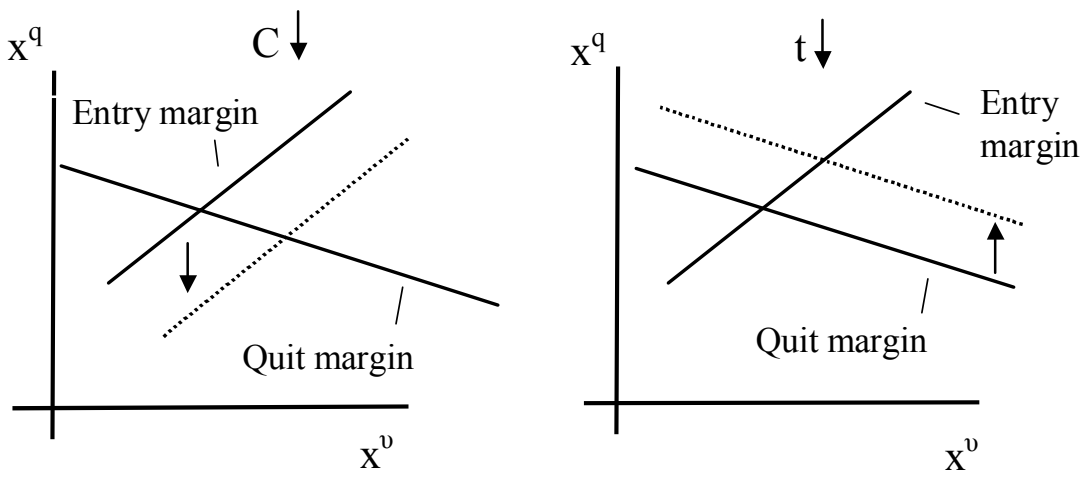

Figure 1: The effects of subsidizing entry (lowering $\mathcal{C}$, left panel) or reducing taxation of market activity (reducing $t$, right panel) on the entry and exit margins.

increase in labour market entrance, as more women will have an incentive to supply market hours. But our simple model immediately shows that the story is more complicated, since a reduction in $\mathcal{C}$ not only raise the entry cut-off point, but it also reduce the quit cut-off point. The overall effect on employment is thus ambiguous. As displayed in the left part of Figure 1, a reduction in $\mathcal{C}$ induces a downward shift in the entry margin along the quit margin, with a reduction of both $x^{q}$ and $x^{\nu}$. What happens to employment is then ambiguous, and depends on the relative density of people that are sitting in the entry or in the quit margin. Note that the fall in the quit margin disappears if $\lambda=0$ since in that case, the quit margin is horizontal. By extension, when $\lambda$ is close to zero, the positive entry effect dominates over the negative quit effect. In terms of welfare, simply note that the lower $\mathcal{C}$, the closer the equilibrium is from the first best neo-classical labor supply model.

\subsection{The Effects of Taxation}

We now consider the second policy, namely the effect of reducing the tax rate $t$. As displayed in the right part of Figure 1, the increase in taxation is equivalent to a shift of the quit margin along the entry margin, leading to a reduction in both the entry and the quit cut-off points. The effect of a reduction in $t$ is now independent of the fact that $\lambda$ is positive or zero, 
and amounts to a an increase in both margins with positive effects on the entry and the quit margin. A reduction in tax shifts people out of home production into full time market activity, increasing both employment and market production.

This is consistent with the literature on the effects of taxation on market activity carried out by Davis and Henrekson (2003). They find a high cross country correlation between taxation and employment rates in high substitution industries such as household and personal services, eating drinking and lodging and retail trade. In as much as women can engage at home in activities that are highly substitutable to market production, a high tax wedge clearly generates an incentive to move away from market production. As a result, a reduction in taxes on those activities has unambiguous effects on employment and market production.

\section{Part-time}

Let us introduce part-time in our simple theory. We assume that workers can now work part-time in the labour market, and have the same productivity per hour $y$ as in full-time activity, and thus the same gross hourly wage $w$. In this discussion, we don't need a full intertemporal structure and set $\lambda$ to zero. We thus simply focus on flow utility, and denote by $W, P$ and $H$ full-time market activity, part-time market activity and full-time home production. Denote by $t$ the tax rate on full-time activity and $t_{1 / 2}$ the tax rate on part-time activity. A large value of $t_{1 / 2}$ can also feature differences in worker's valuation of part-time jobs, such as reduced social security. The indirect utility functions are thus $W(x)=y(1-t)$; $P(x)=\left[x+y\left(1-t_{1 / 2}\right)\right] / 2$ and $H(x)=x$.

It can be remarked that beyond taxes, here there is no specific preference for part-time since there is perfect substituability between home production and market income. Later on in this section we shall relax this assumption. In the baseline model without taxes, there is a single cut-off point $x^{*}=y$ such that

$$
W\left(x^{*}\right)=P\left(x^{*}\right)=H\left(x^{*}\right)
$$


with women below $x^{*}$ are in full time activity and people above $x^{*}$ are in full time home production. If there is a mass point of individuals at $x=y$ then this mass of workers is indifferent between the three states and a positive fraction of them may be in part-time.

Now, suppose that the government wishes to encourage part-time, by reducing taxes on part-time jobs and setting it to $t_{1 / 2}<t$. Let us denote by $\varepsilon$ the relative increment in wages obtained by workers, with of course $\varepsilon=\left(t-t_{1 / 2}\right) /(1-t)$ is decreasing in $t_{1 / 2}$ and increasing in $t$. We assume that the reduction in taxes is financed through a lump-sum tax on all households. The main question we want to address is what happens to market hours and market production.

Intuitively a larger mass of workers take a part-time job and the relevant cut-off values of $x$ are now

$$
\begin{aligned}
x^{h} & =y(1+\varepsilon)=y^{+} \\
x^{w} & =y(1-\varepsilon)=y^{-}
\end{aligned}
$$

since utility is simply given by $W(x)=y ; P(x)=(x+y(1-\varepsilon)) / 2 ; H(x)=x$. People above $x^{h}$ are full time in home production, people below $x^{w}$ are full time on the job and people in the interval $\left[x^{w}-x^{h}\right]$ are in part-time. The subsidy to part-time employment leads to an increase in total employment, since the number of employed women raise from $F(y)$ to $F\left(y^{+}\right)=F(y(1+\varepsilon))$. This is an extensive margin result. Turning to production and thus indirectly to the total number of hours, we have

$$
\begin{aligned}
G D P & =\int_{0}^{y^{-}} y d F(x)+\frac{1}{2} y \int_{y^{-}}^{y^{+}} d F(x) \\
& =\frac{y}{2}\left[F\left(y^{-}\right)+F\left(y^{+}\right)\right]
\end{aligned}
$$

Result 1 : Market GDP is increased by a larger $\varepsilon$ iff if $F$ is locally convex around $y$, i.e. iff $f^{\prime}(y)>0$. For small $\varepsilon$, the effect on market production in absolute value is proportional to $\varepsilon$ and thus disappear as $\varepsilon$ is zero. 
To see this, simply note that $\partial G D P / \partial \varepsilon=\varepsilon y^{3} f^{\prime}(y)$ after a Taylor-extension around $\varepsilon=0$. To understand the ambiguous effect of this result, one has to realize that a subsidy to part time has two effects on market production. On the one hand, it induces women that are full time in home production to enter part-time in the labour market (crowding in effect). On the other hand it induces women who are working full time in the market to swap to part-time (a crowding out effect). The overall effect on market production is thus ambiguous and depends on how the mass of women is positioned around the initial equilibrium. If in the initial equilibrium the mass of women who marginally prefers full time home production is larger (lower) than the mass of women who marginally prefers full time home production (i.e. if the density is locally increasing), the crowding in (out) effect dominates and market production increases (falls). If the two mass of women is identical, than there is no effect on market production. An alternative formulation of this statement is that, if the distribution of $x$ is single-peaked, then subsiding part-time will increase hours and market production if the marginal worker is to the left of the peak, while it would reduce them if the marginal worker is to the right of the peak.

One can also check what happens to aggregate home production $H$, and after few similar steps of algebra one finds that

$$
\begin{aligned}
\frac{\partial H}{\partial \epsilon} & =-\frac{\partial G D P}{\partial \varepsilon}+y^{2} \varepsilon f(y) \\
& =-\varepsilon y^{2}\left[y f^{\prime}(y)+f(y)\right]
\end{aligned}
$$

The first line shows that part of the effect of a relative subsidy to part-time $\varepsilon$ is a transfer from market production to home production, plus a deadweight loss represented by the mass of people at the extensive margin, i.e. $y^{2} \varepsilon f(y)$. The second line indicates that the sign of the effect on home production depends on the sign of the derivative of the function $y f(y)$ with respect to $y$.

There are two possible extensions to this simple model. The first one is to relax the assumption that there is no specific preference for part-time. This is equivalent to relaxing 
the perfect substitutability in $x$ and $y$ and have instead a flow utility $u((1-e) x, e y)$ with $e \in\{0,1 / 2,1\}$ that refers to the hours spent in the market. We can show that in this analytical more complex model a subsidy to part-time would still generate a crowding in and a crowding out effect. The intuition of Result 1 would still carry along, so that the overall effect would still be affected by the slope of the density function $f$ at the cut off points. A second extension would be to introduce worker's heterogeneity on market production rather than on home production. If we assume that market productivity $y$ is dispersed in the population with a c.d.f. $\widetilde{F}$ while $x$ is common to individuals, the problem is formally identical to the one of this paper: we can simply solve it by replacing $W$ by $H$ and vice-versa. The effects of the subsidy on part-time would still depend on the slope of the density $\tilde{f}$ at the initial equilibrium.

\section{Conclusion}

While in Europe there is large consensus on the need to raise the time spent in the market by European women, there is some confusion about the ways in which these goals should be achieved. This paper has presented a simple and original model of labour supply in an imperfect labour market. We showed that subsidies to labour market entry increase women's entrance in the labour market, but they also increase exits from the labour market, with ambiguous effect on employment. Furthermore, subsidies to part-time do increase employment, but they have ambiguous effects on hours and market production. Finally, we show that reductions in taxes on market activities that are highly substitutable with home production have unambiguous positive effects on market employment and production.

\section{References}

[1] Davis, Steve and Henrekson Magnus (2003) The Effects on Work Activity, Industry Mix and Shadow Economy Size: Evidence from Rich Country Comparison, University of 
Chicago Graduate School of Business.

[2] Freeman, Richard and Ronald Schettkat (2002) Marketization of Production and the US-Europe Employment Gap, NBER Working Paper 8797

[3] Garibaldi, Pietro and Etienne Wasmer (2003) Equilibrium Employment in a Model of Imperfect Labor Market, IZA discussion paper 950 (december) and IGIER Working Paper 248.

[4] Pissarides, Chris, Pietro Garibaldi, Claudia Olivetti, Barbara Petrongolo, and Etienne Wasmer (2003) Women in the Labour Force: How Well is Europe Doing?, paper presented at the 5th European Conference of the Fondazione Debenedetti, available on line at www.frdb.org

[5] Prescott Edward, (2002) Prosperity and Depression American Economic Review, 92, May $2(1-15)$ 


\section{IZA Discussion Papers}

\begin{tabular}{|c|c|c|c|c|}
\hline No. & Author(s) & Title & Area & Date \\
\hline 937 & $\begin{array}{l}\text { W. Eggert } \\
\text { L. Goerke }\end{array}$ & $\begin{array}{l}\text { Fiscal Policy, Economic Integration and } \\
\text { Unemployment }\end{array}$ & 2 & $11 / 03$ \\
\hline 938 & $\begin{array}{l}\text { D. Del Boca } \\
\text { A. Venturini }\end{array}$ & Italian Migration & 1 & $11 / 03$ \\
\hline 939 & E. Toulemonde & $\begin{array}{l}\text { Acquisition of Skills, Education Subsidies, and } \\
\text { Agglomeration of Firms }\end{array}$ & 2 & $11 / 03$ \\
\hline 940 & $\begin{array}{l}\text { A. Constant } \\
\text { Y. Shachmurove } \\
\text { K. F. Zimmermann }\end{array}$ & $\begin{array}{l}\text { What Makes an Entrepreneur and Does It Pay? } \\
\text { Native Men, Turks, and Other Migrants in } \\
\text { Germany }\end{array}$ & 1 & $11 / 03$ \\
\hline 941 & $\begin{array}{l}\text { R. V. Burkhauser } \\
\text { J. S. Butler } \\
\text { G. Gumus }\end{array}$ & $\begin{array}{l}\text { Option Value and Dynamic Programming Model } \\
\text { Estimates of Social Security Disability Insurance } \\
\text { Application Timing }\end{array}$ & 6 & $11 / 03$ \\
\hline 942 & $\begin{array}{l}\text { R. V. Burkhauser } \\
\text { J. S. Butler } \\
\text { G. Gumus }\end{array}$ & $\begin{array}{l}\text { Dynamic Modeling of the SSDI Application } \\
\text { Timing Decision: The Importance of Policy } \\
\text { Variables }\end{array}$ & 6 & $11 / 03$ \\
\hline 943 & $\begin{array}{l}\text { J. T. Addison } \\
\text { P. Teixeira }\end{array}$ & $\begin{array}{l}\text { What Have We Learned About the Employment } \\
\text { Effects of Severance Pay? Further Iterations of } \\
\text { Lazear et al. }\end{array}$ & 3 & $11 / 03$ \\
\hline 944 & $\begin{array}{l}\text { H. Görg } \\
\text { D. Greenaway }\end{array}$ & $\begin{array}{l}\text { Much Ado About Nothing? Do Domestic Firms } \\
\text { Really Benefit from Foreign Direct Investment? }\end{array}$ & 2 & $11 / 03$ \\
\hline 945 & $\begin{array}{l}\text { R. Schöb } \\
\text { D. E. Wildasin }\end{array}$ & $\begin{array}{l}\text { Economic Integration and Labor Market } \\
\text { Institutions: Worker Mobility, Earnings Risk, and } \\
\text { Contract Structure }\end{array}$ & 2 & $12 / 03$ \\
\hline 946 & M. Leonardi & $\begin{array}{l}\text { Earnings Instability of Job Stayers and Job } \\
\text { Changers }\end{array}$ & 1 & $12 / 03$ \\
\hline 947 & U. Sunde & $\begin{array}{l}\text { Potential, Prizes and Performance: Testing } \\
\text { Tournament Theory with Professional Tennis } \\
\text { Data }\end{array}$ & 7 & $12 / 03$ \\
\hline 948 & $\begin{array}{l}\text { A. Kugler } \\
\text { G. Pica }\end{array}$ & $\begin{array}{l}\text { Effects of Employment Protection and Product } \\
\text { Market Regulations on the Italian Labor Market }\end{array}$ & 6 & $12 / 03$ \\
\hline 949 & C. J. Flinn & $\begin{array}{l}\text { Minimum Wage Effects on Labor Market } \\
\text { Outcomes under Search with Bargaining }\end{array}$ & 6 & $12 / 03$ \\
\hline 950 & $\begin{array}{l}\text { P. Garibaldi } \\
\text { E. Wasmer }\end{array}$ & $\begin{array}{l}\text { Equilibrium Employment in a Model of Imperfect } \\
\text { Labor Markets }\end{array}$ & 1 & $12 / 03$ \\
\hline 951 & $\begin{array}{l}\text { P. Garibaldi } \\
\text { E. Wasmer }\end{array}$ & $\begin{array}{l}\text { Raising Female Employment: Reflexions and } \\
\text { Policy Tools }\end{array}$ & 5 & $12 / 03$ \\
\hline
\end{tabular}

An updated list of IZA Discussion Papers is available on the center's homepage www.iza.org. 